\title{
Paul Ricœur on collective memory: the cohesion of social life
}

\author{
Maria Cristina Clorinda Vendra*
}

\begin{abstract}
The aim of this article is to present a critical reconstruction of Ricœur's analysis of the complex phenomenon of memory as a collective act of recollection. By focusing the attention on memory as a collective practice, through the use of resources drawn from phenomenology, sociology, and history, I will seek to outline the construction of the collective memorial discourse and its foundations, looking particularly at the eighth chapter of the third volume of Time and Narrative and at the work Memory, History, Forgetting. I will show that our identification and location with others in social collectivities imply to negotiate a gap between subjective and cosmic time. Temporality comes, then, in the plural: our being in time is not merely personal, but rather we are originally involved in a shared social and historical framework.
\end{abstract}

Keywords: Collective memory; Remembering; Narrative; History; Social-phenomenology

\section{Introduction}

"Under history, memory and forgetting. Under memory and forgetting, life. But writing a life is another story. Incompletion"1.

Memory is a complex dimension linked not only to the experience of either the individual or the collectivity, but also to the way in which that very history is read and interpreted in time. Generally speaking, memory can be defined as human being's stratified entity and unique capacity "to preserve traces of the past and to refer actively to them within present situations" 2 . More exactly, with reference to Henri Bergson, Ricœur essentially distinguishes two useful ways to define memory: memory as habits, i.e., as an involuntary repetition of automatized situations and actions, and memory as distinct recollection, that is, as an active involvement of the images of the past ${ }^{3}$. Yet, whereas individual memory has been widely analyzed by traditional philosophy, the notion of

\footnotetext{
* I dedicate this article to the Department of Contemporary Continental Philosophy at the Institute of Philosophy of the Czech Academy of Sciences in Prague (Oddělení Současné Kontinentální Filosofie, Filosofický Ustav AV ČR, Praha), where I am currently working as a Postdoctoral Fellow. E-mail: mcristina.vendra@gmail.com

${ }^{1}$ Ricœur, Paul. Memory, History, Forgetting. Chicago: Chicago University Press, 2004, p. 506

${ }^{2}$ Michel, Johann. Introduction to Mémoires et Histoires. Des identités personnelles aux politiques de reconnaissance. Rennes: Presses Universitaires de Rennes, 2005, p. 9, translation mine.
}

${ }^{3}$ See Ricœur, Paul. Memory, History, Forgetting. p. 24. 
collective memory has been explored as a viable concept in contemporary sociology. It is, then, necessary to understand from a philosophical perspective how individual memory is connected to collective memory and which kind of being collective memory is. Ricœur discusses these themes ranging from cognitive science to sociology, political theory, history, and other relevant disciplines belonging to the social and human sciences. Although he does not address the question of memory in a continuous way in his work, this topic can be considered as an underlying theme in his whole career.

The aim of my essay is to present Ricœur's analysis of the complex phenomenon of memory as a collective act of recollection. The following reflection consists of two intertwined parts. In the first section, I will discuss Ricœur's epistemological and hermeneutical approach to collective memory from his work on narrative. Collective memory will be here examined in connection with history as a form of narrative discourse. I then will draw on Ricœur's socio-phenomenological analysis of collective memory. Specifically, I will show that memory can be considered as a discursive and narrative construction, arising from the individual or collective intentions within a particular sociocultural and historical context.

\section{The narrative understanding of history and the persistence of collective memory}

Collective memory is a notoriously difficult concept to define. Agreeing with Jeffrey Barash's critical reading of Ricœur's interpretation of the notion of collective memory, I argue that collective experience and collective memory can be understood only through the elaboration of an adequate theory of symbol that might account for the complex mediations between human being's personal experience and memory in the common sphere ${ }^{4}$. The analogy Ricœur establishes between personal memory and collective memory is connected with their symbolic and meta-personal sources. Following Ricœur's line of reasoning, I think that collective memory can be coherently conceived as a "web of remembered experiences embodied in collectively communicable symbols" ${ }^{5}$. In other words, collective memory relates to the instituting act of symbolic function as a social inter-space. Ricœur develops his examination of the phenomenon of the collective memory in relation with the problem posed by the cohesion of the collective sphere in the eighth chapter of Time and Narrative 3 and again in Memory, History, Forgetting. More exactly, Ricœur draws the attention on the relation between memory and social cohesion when he introduces his idea of obliged memory. However, whereas in Time and Narrative 3, Ricœur's idea of obliged memory is developed within an epistemological reflection on

\footnotetext{
${ }^{4}$ See Barash, Jeffrey Andrew. Collective Memory and the Historical Past. Chicago: Chicago University Press, 2016, p. 71.

${ }^{5}$ Barash, Jeffrey Andrew. Collective Memory and the Historical Past, p. 87.
} 
historical knowledge as "standing for" or "taking the place of" (Lieutenance), distinguished from representation as "giving oneself a mental image of some absent external thing" ${ }^{6}$, in Memory, History, Forgetting, he discusses again his idea referring to various other philosophical and sociological approaches. I argue that Ricœur's analysis of collective memory moves from an earlier epistemological and hermeneutical discussion concerning narrative as a way of characterizing historical knowledge to a phenomenological approach developing from the question of remembrance (What is remembered?), passing through reminiscence (Who remembers?), and leading to reflexive memory (How does one remember?). The connection between collective memory and the reconstruction of the historical past leads the author to reflect on the historicity of human modes of understanding and being. Let us focus on the underlying continuity connecting up these two approaches to the problem of collective memory. These reflections allow us to show the evolution of Ricœur's conception of collective memory from his work on narrative to his last book, Memory, History, Forgetting, published in 2000. Specifically, in this last work the topic of collective memory is developed by introducing new concerns. As David Pellauer puts it, "something new is added [...] with the turn to memory and forgetting, which reflects new issues that had drawn Ricœur's attention"7.

The epistemological-hermeneutical and the phenomenological approach to collective memory have a question in common, namely, the question of the representation of the past: how can we make present what is past, which is irredeemably absent? First, the notion of collective memory is connected with the analysis of the conditions of possibility of history as a form of narrative discourse. History involves the deployment of certain literary practices, such us plot, composition, character, point of view, and so on. Historical discipline refers to the temporal character of our existence for the sake of refiguring it. As a narrative discourse, history is meaningful to the extent it portrays human being's temporal features of existence. Embedded in history as actors in a spacetemporal plot, we have to consider the past as having two meanings: past is no longer there yet still there, i.e., it is at once absent and present. History is an indirect knowledge developed through the use of traces. Notably, traces are history's final epistemological presuppositions. The historical explanatory comprehension of the course of action is also supported by the eyewitness testimony of human beings concerning events of the past. According to Ricœur, historical knowledge "stands for the past, it represents the past, not in the sense that the past itself would appear in the mind (Vorstellung) but in the sense that

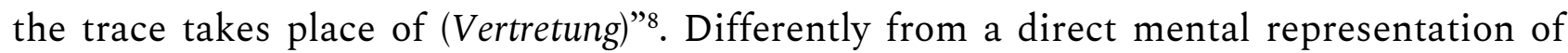
objects, history is mediated by the traces of the past. These traces represent the past through mimesis, i.e., they take the place of the past. Without recapitulating Ricœur's

\footnotetext{
${ }^{6}$ Ricœur, Paul. Time and Narrative, vol. 3. Chicago: Chicago University Press, 1988, p. 143.

${ }^{7}$ Pellauer, David. Ricœur: A Guide for the Perplexed. London: Continuum, 2007, p. 109.

${ }^{8}$ Ricœur, Paul. Time and Narrative, vol. 1. Chicago: Chicago University Press, 1984, p. 58.
} 
careful examination of the successive levels that characterize the historical knowledge as a narrative discourse, I want to stress here that the duty of memory as "the duty to do justice, through memories, to an other than the self'9 cannot be understood separately from human capacity to narrate. In this regard, Ricœur's idea of collective memory can be understood in the context of his analysis of historical knowledge.

With the overlapping of existential, social, and empirical aspects, Ricœur's dynamic model of reconstruction of historical reality discloses an essentially paradoxical character. On the one hand, historical knowledge is a realistic claim to grasp the past as a reality that really was through the use of archives and documents that bear witness to the past. On the other hand, Ricœur sees a necessary convergence between history and fiction. This means, for the author, that historical knowledge has to turn to imagination for help: fiction is what allows the historian to unveil concrete possibilities, that is, to focus on what might have been. The documentary proof and the imaginative productive understanding interweave in the historian's process of reconfiguration of human being's past. As such, while preserving the aspiration to truthfulness, history captures the past by transporting the historical reality into an analogical narrative. Since historical narrative discourse stands for the past reality in terms of "such as", the ontological status of historical representation can be defined, I believe, as a metaphorical status. History can, therefore, re-enact the past and recreate, by means of productive imagination, the past in the timeline of the story. As Ricœur writes in the eighth chapter of Time and Narrative 3, "concretization is obtained only insofar as, on the one hand, history in some way makes use of fiction to refigure time and, on the other hand, fiction makes use of history for the same ends" ${ }^{10}$. History and fiction interweave in the narration of the past. Hence, the narrative reenactment of history is linked with a productive imaginative understanding of the past as something that is no more. Historians deploy novelistic techniques in order to make things vividly visible as if they were present. Nevertheless, historians have to be careful since "the danger is, of course, that the figural 'as if might collapse into a literal belief, so that we would no longer merely 'see-as' but make the mistake of believing we are actually seeing" 11 . Richard Kearney observes that "this 'hallucination of presence' (easily conducive to dogmatism and fundamentalism) calls, in Ricœur's view, for ethical vigilance by historians in to sustain a proper dialectical balance between empathy and distance" ${ }^{12}$.

History re-appropriates the past as present and at the same time opens up a duty to the otherness of the past. As such, history deals with a dual fidelity to past as sameness and difference. Following this line of reasoning, we can stress that there is a fundamental

\footnotetext{
${ }^{9}$ Ricœur, Paul. Memory, History, Forgetting, p. 89.

${ }^{10}$ Ricœur, Paul. Time and Narrative, vol. 3, p. 181.

11 Kearney, Richard. Narrative Imagination: between Ethics and Poetics. In: The Hermeneutics of Action. London: Sage, 1996, p. 179.

${ }^{12}$ Kearney, Richard. Narrative Imagination: between Ethics and Poetics, p. 178.
} 
relation between historical knowledge as a narrative discourse and otherness. As Ricœur rightly points out, standing for the others of the past, history allows for different readings and interpretation. Historical discourse is, then, a social public discourse calling for multiple readings. The author defends the thesis that narratives testify to what he understands as human being's debt toward history in refiguring the past. Historical discourse responds, then, to the ethical summons to respect the reality of the past. Consequently, Ricœur claims that historical discourse is ethically responsible and expresses "the debt we owe the dead" ${ }^{13}$. As he puts it, historians are "bound by a debt to people from earlier times, to the dead. It is the task of philosophical reflection to bring to light the presuppositions underlying this tacit realism"14. It is in this interpretative framework that the notion of collective memory as an obliged form of memory arises.

Collective memory relates to the sum of all possible historical narratives that testify to the past. Agreeing with Ricœur, David Klemm observes that "historical narratives aim to recount the lived time of past events against cosmic time and owe a specific obligation to the memory of the dead, an obligation that makes history accountable to the documentary archives" ${ }^{15}$. Therefore, through historical narratives human being expresses the experience of feeling obligated to remember what happened in the past. For example, this experience finds expression in the process of mourning. Obliged memory is inserted within the unitary flow of human being's lived experience. More precisely, through historical discourse, human beings experience their duty to remember the others of the past and to do justice to these others. In this speculative context, the historical plot is conceived as "a servant of the memory of past human beings"16. Through historical knowledge we pay off on our debt to the memory of past human beings. The notion of debt is "inseparable from the notion of heritage" 17 . Differing from the idea of guilt, debt is connected with the remembering of other people, namely, with the possibility to make the "inventory of the heritage of those who have gone before us" ${ }^{18}$. Historiography has to live up the task of memory, it is not moved by curiosity alone, but "there are crimes that must not be forgotten, victims whose suffering cries less for vengeance than for narration. The will not to forget alone can prevent these crimes from ever occurring again" 19 . Ricœur specifies that "among those others to whom we are indebted, the moral priority belongs to the victims [...] The victim at issue here is the other victim, other than ourselves" ${ }^{20}$.

\footnotetext{
${ }^{13}$ Ricœur, Paul. Time and Narrative, vol. 3, p. 184.

${ }^{14}$ Ricœur, Paul. Time and Narrative, vol. 3, p. 100.

${ }^{15}$ Klemm, David. Philosophy and Kerygma. Ricour as Reader of the Bible. In: Reading Ricœur. New York: State University of New York Press, 2008, p. 58.

${ }^{16}$ Ricœur, Paul. Time and Narrative, vol. 3, p. 156.

${ }^{17}$ Ricœur, Paul. Memory, History, Forgetting, p. 89.

${ }^{18}$ Ricœur, Paul. Memory, History, Forgetting, p. 89.

${ }^{19}$ Ricœur, Paul. Time and Narrative, vol. 3, p. 189.

${ }^{20}$ Ricœur, Paul. Memory, History, Forgetting, p. 89.
} 
Otherwise put, collective memory is an obligation to do justice to human beings that as victims have suffered injustice in history. Blending history and fiction, our personal and our group identity are reliant on an ethical and social engagement with the other as an interdependent, subjective, and contingently situated being. Through the reading and the telling of histories, we explore collective memory as a source of social cohesion connecting through the symbolic structure of human being's experience the individual and the collective, the past and the present. Surely, memory is linked with human being's responsibility for the past taken as a singular selfhood, but also and at the same time memory and the responsibility for the past are analogically extended to human being's capability to perform actions "with and for others in just institutions" ${ }^{21}$. History is, then, a narrative discourse in which we can experience our obligation to the memory of the past and where we can find inspiration to perform responsible actions. As such, the mistakes of the past and the practices of mourning within particular communities can concretely help human beings in making future decisions and actions.

\section{For a social phenomenology of collective memory}

In Memory, History, Forgetting, Ricœur takes up once again the problem of the faithful or truthful representation of the past. The concern of the continuity and the discontinuity between history and fiction is considered in relation to the theme of memory. More exactly, the author proposes an inquiry into the reality of the historical past invoking an analysis on memory as an active instrument that reverberates immediately from the individual to the collective level. By taking up memory as a topic in its own right, Ricœur seeks to show to what extent historians are dependent on memory and to what extent they have to go critically beyond it. The use of commemorative memory and its possible abuse at the level of social praxis leads to a reflection on forgiveness particularly in its political form. The epistemological and hermeneutical reliable perspectives of reconfiguration of the past, shaped by systematic explanatory moves, are now inserted within a broader phenomenology of memory. This renewed approach to the reality of the historical past begins with the analysis of the object of memory, that is, of the souvenir "that one has before the mind"22, it passes through the search for a given memory, i.e., though amnesia or recollection, and finally moves to reflective memory, namely, to memory as it is exercised. The topic of memory is the unifying thread of these three parts of the book. In other words, the phenomenological analysis of memory is developed through an anthropological inquiry and an epistemological approach, converging into an

\footnotetext{
${ }^{21}$ Ricœur, Paul. Oneself as Another. Chicago: Chicago University Press, 1992, p. 172.

${ }^{22}$ Ricour, Paul. Memory, History, Forgetting, p. xvi.
} 
ethical and political concern regarding memory as a work that moves from repetition to active remembrance.

I argue that Ricœur's work on Memory, History, Forgetting, can be read backwards so as to shed light on presuppositions that occurred in reaching that speculative point. It is my contention here that the second section of the work clearly recalls Ricœur's earlier reflections of narrativity as the production of human time and history. I think that this part can be coherently seen as a further elaboration of his epistemology of history. Indeed, he discusses again the three phases of historical operation: the stage of archives, the explanation and understanding phase, and the representation of the past on the representative level, while focusing his attention on the connection between memory and the historian's intention to produce a truthful reconfiguration of human being's historical past. This proves that there is an unavoidable continuity that runs throughout Ricœur's analysis of history from his earlier works to his last masterpiece ${ }^{23}$.

In Memory, History, Forgetting, Ricœur introduces in a short section the idea of collective memory arising out of the consideration of the sociology of the collective memory and the phenomenology of the individual memory. The notion of collective memory renews the interest on the question "Who?" since we can always ask to whom this memory belongs. In Time and Narrative and in Oneself as Another, the author clearly observes that we can give an answer to this question by using personal pronouns. As he puts it, "the question 'Who did this?' can be answered by using a demonstrative pronoun (he, she, this one, that one), or by giving a definite description (so and so). These replies render something in general a someone" ${ }^{24}$. Pronouns are "means of designation from which the self-designation of the speaking subject follows" ${ }^{25}$. According to Ricœur the capacity to remember is attributed to "all the subjects that find lexical expression in one or the other of the personal pronouns" ${ }^{26}$. As such, I can speak of my memory, of your memory, of his or her memory, of our memory and their memory. Memory is a plural phenomenon.

Language is what directs the self-designation. Ricœur writes: "memory enters into the region of language; memories spoken of, pronounced are already a kind of discourse that the subject engages in with herself. What is pronounced in this discourse occurs in the common language, most often in the mother tongue, which is the language of others" 27 . Therefore, Timo Helenius observes that in Ricœur's thought "the act of selfdesignation is linked to the capacity to remember through linguistic mediation - the notion of myself is gathered in the midst of language that clarifies my relation to my acts

\footnotetext{
${ }^{23}$ See Ricœur, Paul. Memory, History, Forgetting, p. 280.

${ }^{24}$ Ricœur, Paul. Oneself as Another, p. 59

${ }^{25}$ Ricœur, Paul. The Course of Recognition. Cambridge: Harvard University Press, 2005, p. 95.

${ }^{26}$ Ricœur, Paul. The Course of Recognition, p. 104.

${ }^{27}$ Ricœur, Paul. Memory, History, Forgetting, p. 129.
} 
by ascribing those very acts to me as their agent" ${ }^{28}$. Ricœur pushes this discourse much further. The analysis of the role and the nature of language, leads him to elaborate on the relations between personal and collective memory. On the one hand, if memory is limited to individuals, there arises the risk of "isolating recalled memories by making them depend on specific egos" ${ }^{29}$. On the other hand, memory must not be reduced to a superconcept or a substantial principle, that is, to a sort of Hegelian objective spirit. Let me focus on Ricœur's critical analysis of these two extremes. I argue that reflecting on the problem of the connection between individual and collective memory, Ricour further elaborates his socio-phenomenology strictly dependent on his earlier phenomenological approach to vulnerability and to his hermeneutics of the self as a wounded ego-cogito.

The comprehension of the precise contours of the idea of collective memory implies to extend the socio-philosophical reflection beyond oneself and the other seen as individual human beings in order to encompass identity in its collective dimension. Collective Memory is something collectively experienced in the past that truly lies at the heart of our shared identity. The analysis of collective memory and the cohesion of life in common are complex socially and politically charged connected phenomena. Ricœur's task to elaborate on collective memory and on the social cohesion of the collective sphere of human life from a socio-phenomenological standpoint is accompanied by the most significant explanatory resources of his hermeneutical thinking. Specifically, the author begins by inquiring about the responses to the question of collective memory given by two past philosophical and sociological orientations: John Locke's empirical perspective and Maurice Halbwachs's writings on the social construction of memory.

Locke's philosophical approach to the nature of individual memory and Halbwachs's sociological contribution to that topic show important sources of the presuppositions concerning memory in the Western tradition. The investigation of these two different and opposing attempts provides the conceptual framework, i.e., the basic theoretical horizon within which Ricœur's notion of collective memory itself becomes intelligible. Thus, let me briefly sketch Locke's and Halbwachs's antithetical contributions to the topic of memory, before I move on to Ricœur's position. I argue that the study of these two different approaches has a great impact on Ricœur's conception of collective memory. In other terms, I believe that a helpful outline of his basic orientation to the topic of collective memory can be drawn in relation to the work of Locke and Halbwachs.

In the context of the rise of the modern Western nation-state, of political liberalism and market economy, John Locke's thought represents a clear individualistic reaction against political absolutism, that is, against any political hierarchical framework in which

\footnotetext{
${ }^{28}$ Helenius, Timo. Ricour, Culture, and Recognition: A Hermeneutic of Cultural Subjectivity. London: Lexington, 2016, p. 61.

${ }^{29}$ Pellauer, David. Ricœur: A Guide for the Perplexed, p. 112.
} 
rights are vested in the nobility. Positioning himself within classical liberalism, this English theorist of the social contract conceives human beings as individual entities free to do anything they desire so long they do not infringe on the rights to life, liberty, and property of others. Grounding his social analysis on the fact that each human being is a rights-bearer, for Locke any society and any group is the sum of the individuals who compose it. Otherwise put, community is an arithmetical sum of human beings. What held together collective existence is the economic interaction and the contract established among atomistic individuals in a framework provided by political institutions. The definition of individuals as bearers of rights is connected with the concept of memory as constitutive of our personal identity, as a necessary condition for our autonomy and legal responsibility.

In Locke's view, memory is conceived as a storehouse from which we can exact images of past events and retrieve past experiences at any time without any loss of information. Specifically, personal identity is tied to the continuity of consciousness. For Locke, consciousness is what allows the identity of a human being to persist over time. There is, then, an equation between consciousness, personal identity, and memory. As he writes in his An Essay Concerning Human Understanding (1689) it is

the same consciousness that makes a man be himself to himself, personal identity depends on that only, whether it be annexed only to the individual substance, or can be continued in a succession of several substances. For as far as any intelligent being can repeat the idea of any past action with the same consciousness it has of it at first, and with the same consciousness it has of any present action, so far it is the same personal self ${ }^{30}$.

In this attempt to define human being's personal identity in terms of memory, it can be said that the consciousness of the past is, at least, the same as memory. In sum, personal identity relies on memory as one's own conscious ability to recall past experiences. Therefore, we can coherently conclude that in Locke's perspective the priority always falls on the side of individual memory.

Maurice Halbwachs, in contrast to Locke's methodological individualism, argues that historical memory and collective memory have priority over autobiographical individual memory and personal memory. Belonging to the second generation of the Durkheimian school of sociology, according to Halbwachs, memory is not a phenomenon pertaining only to human being as an individual being, but rather it is inevitably socially conditioned even in the most individual aspects. Otherwise put, memory is a social fact that confers identity on individuals and groups. Individual memory depends, then, upon collective memory. As Halbwachs argues: "no memory is possible outside frameworks used

${ }^{30}$ Locke, John. An Essay Concerning Human Understanding (1689). London: Dent, 1976, p. 163. 
by people living in society to determine and retrieve their recollections" 31 . Therefore, memory is delivered from different social frameworks and collectivities such as the family, the generation, the nation, etc.

According to Ricœur, we can recognize a negative and a positive level in Halbwachs's reflection on memory. First, for Ricœur, the negative argument can be resumed as follows "when we no longer belong to the group in the memory of which a given recollection is preserved, our own memory is weakened for lack of external supports" ${ }^{32}$. On the other hand, the positive level consists in the acknowledgment that our personal remembering can occur only where we situate ourselves "within the viewpoint of one or several groups and one or several currents of collective thought" 33 . Human memories always take place in socially marked places. These social frameworks of memory provide human being with the means for ordering and organizing his or her memories. In short, it is in these social contexts that we can find the preconditions for recollecting experiences and for making them meaningful. As such, the social framework is considered as an inherent part of the work of recollection. In Halbwachs's perspective, as Ricœur observes, "adult memories do not differ from childhood memories. They make us travel from group to group, from framework to framework, in both spatial and temporal sense. Recognizing a friend from a portrait sends us back to the milieu where we have seen him" ${ }^{34}$. Therefore, instead of a universal kind of collective memory, the French sociologist claims that there is necessarily a multiplicity of collective memories representing the various groups that constitute our belonging. Halbwachs clearly claims that: "a man who remembers alone what others do not remember resembles somebody who sees what others do not see. It is as if he suffers from hallucinations" 35 . Memory enables the social link among individuals, family traditions, customs of class, beliefs, and places. What seems to me significant in Halbswachs's analysis is the fact that memory is basically a social action based on our lived experience, namely, it is an active production of ourselves as social beings. Personal remembering is collective since we collect our remembered experience in the social contexts of past experience within the socially situated remembering in the present. In this way, "we produce expanded versions of ourselves as social beings by bringing into view distinctions only visible by comparing our experience across two different social milieus". In conclusion, following Halbwachs's view, remembering is a collective shared framework of meaning determined by the various social groups to which we belong. We cannot exercise our memory as a-social individuals, but rather as social

\footnotetext{
${ }^{31}$ Halbwachs, Maurice. On Collective Memory. Chicago: Chicago University Press, 1992, p. 43.

${ }^{32}$ Ricœur, Paul. Memory, History, Forgetting, p. 121.

${ }^{33}$ Halbwachs, Maurice. On Collective Memory, p. 33.

${ }^{34}$ Ricœur, Paul. Memory, History, Forgetting, p. 122.

${ }^{35}$ Halbwachs, Maurice. On Collective Memory, p. 167.
} 
beings belonging to different groups. Based on spatial and temporal reconstruction, if memory is not located in the social space of a group it necessarily fails.

In his mature thought, Ricœur offers a mediating position between these two polar opposite perspectives. First, the author acknowledges that Locke's model has the merit of making memory a criterion of personal identity. Locke gives greater prominence to the fact that memory is something properly mine: it is my own memory. As Ricœur observes,

asserting the possession of memories as one's own constitutes in linguistic practice a model of mineness for all psychical phenomena [...] it was John Locke who, by virtue of the flexibility of the English language, began to theorize the operation by introducing the expression 'appropriate' as well as a series of semantic moves with the word 'own' taken in its pronominal or verbal form ${ }^{36}$.

Yet, Ricœur especially appreciates that within the framework of his theory of memory, Locke rejects the Cartesian solution to the problem of personal identity in terms of substantial unity. Accordingly, Locke argues that "personal Identity consists, not in the Identity of Substance, but [...] in the identity of consciousness" ${ }^{37}$. Otherwise put, for Locke, it is not the fact of being the same substantial substrate that ensures human being's identity, but it is only the consciousness and the continuity of memory that he or she has of himself or herself as being one and the same person to make identity an "uninterrupted continuity between the first and last stage in the development of that which we can consider to be the same individual" 38 . In a crucial comment in Oneself as Another, Ricœur recognizes that, through the rejection of substantiality and the adaptation of psychological continuity as the main criterion for our self-identity, Locke has anticipated a concept which will occupy a central place in his social ethics: that of selfhood. By this remark, Ricœur emphasizes that Locke's thought introduces "a caesura in his analysis without having to give up his general concept of the sameness of a thing with itself. And yet the turn to reflection and memory did, in fact, mark a conceptual reversal in which selfhood was silently substituted for sameness" 39 .

Nevertheless, Ricœur sees in Locke's conception of memory two major difficulties. The first concerns Locke's argument that self-identity consists in the consciousness that human being has as being one and the same though memory. Ricœur observes:

to Locke and his partisans will be regularly opposed the aporias of an identity hinging on the testimony of memory alone; psychological aporias concerning the limits, the intermittence (during sleep, for example), and the

\footnotetext{
${ }^{36}$ Ricœur, Paul. Memory, History, Forgetting, pp. 124-125.

${ }^{37}$ Locke, John. An Essay Concerning Human Understanding (1689), p. 214.

${ }^{38}$ Ricœur, Paul. Oneself as Another, p. 117.

${ }^{39}$ Ricœur, Paul. Oneself as Another, p. 126.
} 
failings of memory, but also more properly ontological aporias: rather than saying that a person exists inasmuch as that person remembers, is it not possible, Butler will ask, to assign the continuity of memory to the continuous existence of a soul-substance? Without having foreseen it, Locke revealed the aporetic character of the very question of identity ${ }^{40}$.

Second, Locke's perspective comes up against another serious challenge, notably the well-known following problem of social atomism whereby society is seen as nothing more than a collection of individuals. In this social framework, where human beings as self-interested, equal, and rational social atoms are aggregated together on the basis of the social contract, all other forms of collective identity are extraneous to the formation of this society. Without the articulation of the social contract, collective identity is destined to be absent. That is to say, if the social contract did not exist, human beings would be deemed to lack a sense of themselves as constituting a group or a collectivity, i.e., what Locke calls "one body". Ricœur rejects such an individualistic starting point. Against Locke's perspective, he thinks that Lockean position of social atomism and political contractualism can hardly account for the complex lines of social cohesion. For Ricœur, society is a very concrete reality and not a mere assemblage of individuals who remain divided even when together. In other words, as Barash critically stresses, Ricœur believes that "beyond a series of individual identities constituted by personal recollections" 41 it is necessary to "search for an appropriate principle of social cohesion" 42 . Following the elaboration of Ricœur's thought, I argue that the ultimate meaning of one's individual life, as fundamentally an ontologically relational life developing within the plural web of relationships, provides the theoretical ground for thinking social cohesion.

Aware of the limits of Locke's empiricism, Ricœur directs a critical analysis to the idea of collective memory and social collectivity elaborated by Maurice Halbwachs. According to Ricœur, Halbwachs fails to recognize the individual. Although the French social scientist clearly emphasizes that individual members might "vary in the intensity with which they experience group memories" 43 , he adds that "each memory is a viewpoint on the collective memory, that this viewpoint changes as my relationships to other milieus change" ${ }^{44}$. Therefore, common memory is differently experienced by each human being within varying contexts. As the French historian Pierre Nora notes, for Halbwachs "memory wells up from groups that it welds together, which is to say [...] that there are as

\footnotetext{
${ }^{40}$ Ricœur, Paul. Oneself as Another, p. 126.

${ }^{41}$ Barash, Jeffrey Andrew. The Place of Remembrance. In: A Passion for the Possible: Thinking with Paul Ricœur. New York: Fordham university Press, 2010, p. 149.

${ }^{42}$ Barash, Jeffrey Andrew. The Place of Remembrance, p. 149.

${ }^{43}$ Halbwachs, Maurice. On Collective Memory, p. 48.

${ }^{44}$ Halbwachs, Maurice. On Collective Memory, p. 48.
} 
many memories as there are groups, that memory is by nature multiple yet specific" 45 . However, agreeing with Barash's critical reflection on collective memory ${ }^{46}$, I believe that in Halbwachs's perspective individual memory is effectively displaced into the collective one. Even if on the one hand it is true that Halbwachs recognizes that memory is plural and yet individual, on the other hand the individual dimension of memory is absorbed in the social and collective frameworks. In short, I argue that going beyond Durkheim's focus on the social, Halbwachs's emphasis on the notion of collective memory is favored at the expense of the individual act of recollection. Accordingly, discussing the complexity of Halbwachs's sociological position, Ricœur emblematically observes:

But does Halbwachs not cross an invisible line, the line separating the thesis 'no one ever remembers alone' from the thesis 'we are not an authentic subject of the attribution of memories'? Does not the very act of 'placing oneself in a group and of 'displacing' oneself or shifting from group to group presuppose a spontaneity capable of establishing a continuation with itself? If not, society would be without any social $\operatorname{actors}^{47}$.

Following Ricœur's line of reasoning, Halbwachs is critically accused of depriving the individual of his own memory. In other terms, Ricœur strongly criticizes Halbwachs for having gone too far leading to the conclusion that "we are not genuine owners of our own memories" 48 . Nonetheless, for Ricœur, Halbwachs's "surprising dogmatism” ${ }^{49}$ does not provide grounds for dismissing the recognition of a remarkable aspect of his work. More exactly, Ricœur accepts Halbwachs's thesis that no one ever remembers alone, we always remember with others and with the help of others.

Undoubtedly, human being's memory makes use of the memories of others and grows up surrounded by social phenomena and gestures, images and landscapes. But instead of building on the thesis that individual memories are fragments of an allencompassing collective memory, for Ricœur collective memories emerge from the interaction and the productive exchange of individual memories within a framework provided by societal memory. As Robert Bevan observes, Ricœur's argument "leads, to some extent, to a homogenization: a shared memory and, consequently, a shared attitude to representations of the past - including architecture" ${ }^{50}$. In this assessment, individual memory and communal memory, which are rooted in public space and in social structures,

\footnotetext{
${ }^{45}$ Nora, Pierre. Between Memory and History: Les Lieux de Mémoire. Representations, Special Issue: Memory and Counter-Memory, v. 26, n. 1, 1989, p. 12.

${ }^{46}$ Barash, Jeffrey Andrew. The Place of Remembrance, p. 149.

${ }^{47}$ Ricœur, Paul. Memory, History, Forgetting, p. 122.

${ }^{48}$ Ricœur, Paul. Memory, History, Forgetting, p. 149.

${ }^{49}$ Ricœur, Paul. Memory, History, Forgetting, p. 123.

${ }^{50}$ Bevan, Robert. The Destruction of Memory: Architecture at War. London: Reaktion Books, 2006 , p. 42.
} 
exist in multidirectional and simultaneous relationships. The social locations of meaning specific to remembering practices are always implicated in the ways in which mediated representation of the past are imagined and transposed. At this point, in commenting on Halbwachs's work, Ricœur points out that, in the first instance, "it was the personal act of recollection that the mark of the social was initially sought and then found. This act of recollection is in each case ours. To believe this, to attest to it, cannot be denounced as a radical illusion" ${ }^{51}$. Yet, using a quasi-Leibnizian idea of perspective, Halbwachs adds that

while the collective memory endures and draws strength from its base in a coherent body of people, it is individuals as group members who remember [...] I would readily acknowledge that each memory is a viewpoint on the collective memory, that this viewpoint changes as my position changes, that this position itself changes as my relationships to other milieu change $\mathrm{s}^{52}$.

Ricœur succinctly argues that naively "Halbwachs himself believes that he can place himself in the position of the social bond, when he critiques it and contests it" 53 . In brief, the French philosopher rejects Halbwachs's idea of social framework and collectivity as something unilaterally imposed to every individual consciousness. Finally, the he concludes that Locke's and Halbwachs's perspectives lead

to the same negative conclusion: whether we consider the sociology of collective memory or the phenomenology of individual memory, neither has any great success than the other in deriving the apparent legitimacy of the adverse position from the strong position each, respectively, holds: on the one side, the cohesion of the states of consciousness of the individual ego; on the other, the capacity of collective entities to preserve and recall common memories ${ }^{54}$.

After carefully having weighed up the arguments and counter arguments, Ricœur locates his own elaboration of the notion of collective memory squarely within the history of philosophy and the social scientific studies, aiming at epitomizing the relation between individual and plural identity in the social sphere. Acknowledging an intrinsic relationship between memory and identity, individuality and collectivity, the French author attempts to locate collective memory in an intermediary zone. In this way, in Ricœur's phenomenology of memory, the notion of collective memory assumes an intermediary configuration between the idea of individual's memory, as it is exemplified in the work of John Locke, and the assumption that common memory is an entity standing above and beyond the

\footnotetext{
${ }^{51}$ Ricœur, Paul. Memory, History, Forgetting, p. 123.

${ }^{52}$ Halbwachs, Maurice. On Collective Memory, p. 48.

${ }^{53}$ Ricœur, Paul. Memory, History, Forgetting, p. 123.

${ }^{54}$ Ricœur, Paul. Memory, History, Forgetting, p. 124.
} 
individuals constituting it, as it is presented in the sociological approach of Halbwachs. Otherwise put, the question of collective memory arises together with the problem concerning the way in which the principle of cohesion of plural existence is formulated. Thus, Ricœur's elaboration of the concept of collective memory is linked to the determination of a principle needed to understand the collective sphere as a being-incommon. As Barash comments, Ricœur's phenomenology of collective memory is parallel to the task of finding a principle of the common social world which would be

capable of avoiding the two opposing tendencies which have continually hunted ethico-political theory in the modern world: at the one end, the Scylla of atomized private interests out of which collective cohesion is supposed to spontaneously spring; at the other end, the Charybdis of the crushing domination by the organic State, conceived as a Volksgeist or, to speak the twentieth-century totalitarian language which distorted Hegel's thinking, as 'substantial homogeneity's5.

From Locke's approach to memory, I believe that Ricœur is influenced to direct his attention at the side of individual memory. We must not lose sight of the fact that individual memory is closely connected to the inwardness associated with our personal experience, that is, it is linked to the mineness of lived selfhood and with its endurance over time. However, against David Pellauer's interpretation of Ricœur's philosophy, I believe that it is not completely correct and even dangerous to argue that for Ricœur "the priority will always fall on the side of individual memory" ${ }^{56}$. If, on the one hand, it is true that Ricœur attempts to preserve both personal identity and memory from being absorbed ecstatically into the collective processes, on the other hand, though, I argue that in Ricœurian conceptualization of identity, he highlights human being's individuality cannot exist apart from the collective context. This is just another way to say that human being is ontologically a socially situated relational being whose life can be interpreted and explained only in relation to others. In Ricœur's thought, then, I think that there is a dialectical balance between the view of each person as singularity and the common life of the greater collectivity.

This delicate balance between individuality and plurality, as a fil rouge that permeates all aspects of Ricœur's thought, is clearly reflected in his phenomenological approach to collective memory. Not surprisingly, after the exploration of the complementary resources arising from Locke's and Halbwachs's perspectives on memory and common life, in attempting to steer between these two extremes, Ricœur goes back to Husserl's phenomenology. More exactly, Ricœur returns to and retrieves once again the

\footnotetext{
55 Barash, Jeffrey Andrew. The Politics of Memory. In: Questioning Ethics: Contemporary Debates in Continental Philosophy. London: Routledge, 1999, pp. 33-34.

${ }^{56}$ Pellauer, David. Ricour: A Guide for the Perplexed, p. 112.
} 
elements of the fifth of Husserl's Cartesian Meditations concerning the apprehension of the coexistence between the polarity of the transcendental Ego and the Egos of the others. In sum, Husserl's goal is to explain and examine the possibility of comprehending the constitution of the communal context. Without recapitulating Ricœur's polemical attack to Husserl's totalizing idealism, what is of crucial importance here is Husserl's theory of "apperceptive transfer" or "analogizing appresentation" as a useful model for understanding the connection between individual and collective memory. Yet, for the reasons stated above, in my opinion it would be incorrect to speak of a passage from individuality to collectivity and vice-versa. For Husserl, the a-priori appresentation constitutes the condition of possibility of grasping the other in the communal sphere. According to the German phenomenologist, the other cannot be given to us in an original way, but only through analogy. More precisely, the other is seen as a modification of the ego, that is, the other is given through a prior understanding of ourselves and through an irreducibly mediated intention. Conceiving the other "in me, yet as other", opens up the possibility of apprehending others as communal others.

As Barash observes, the analogical appresentation serves to Husserl as "the starting point for a theory of intersubjectivity at the different levels of articulation of the social world, from interpersonal interaction to 'the higher intersubjective communities' that designate larger collectivities" 57 . However, differently from Ricœur's perspective, Husserl's theory of the constitution of communities is not grounded on the work of collective memory. Ricœur writes:

the final paragraphs of the famous "Fifth Cartesian Meditation" do indeed propose the theme of "communalization" of experience at all its levels of meaning, from the foundation of common ground of physical nature to the celebrated constitution of 'higher intersubjective communities' (still called 'personalities of a high order'), a constitution resulting from a process of 'social communalization'. We certainly do not encounter the word 'common memory' in this broadened context of transcendental phenomenology, but it would be perfectly in harmony with the concept of 'worlds of culture', understood in the sense of 'concrete lifeworlds in which the relatively or absolutely separate communities lives their passive and active lives' ${ }^{58}$.

Agreeing with Barash's critical reading on the topic of collective memory, I argue that the absence of this notion in Husserl's work is not astonishing. In his theory of interpersonal communities, Husserl conceives the self-certitude of the transcendental ego as "an absolute basis for meaningful interaction in the common life-world, independent of

\footnotetext{
${ }^{57}$ Barash, Jeffrey Andrew. Collective Memory and the Historical Past, p. 74.

${ }^{58}$ Ricœur, Paul. Memory, History, Forgetting, p. 118.
} 
historical flux and contingency"59. Although Ricœur flatly rejects Husserl's foundational subjectivity and his claim for an absolutely certain grounding, in his thought on collective memory he draws inspiration from Husserl's principle of analogy. In other terms, Ricœur uses analysis as a critical principle that allows us to make intelligible the relation among human being's personal life, social cohesion, and collective memory. Accordingly, Ricœur claims:

it is only by analogy, and in relation to individual consciousness and its memory, that collective memory is held to be a collection of traces left by the events that have affected the course of the history of the groups concerned, and that it is accorded the power to place on stage these common memories, on the occasion of holidays, rites and public celebrations ${ }^{60}$.

In short, inspired by Husserl's notion of analogy, in his theory of collective memory, Ricœur stresses that there is an analogical relation between individuals and groups. In other terms, we can argue that Ricœur's theory of collective identity and collective memory depends on the strict analogy that connects individual and community. My purpose here is not to deny the role that analogies play between individuality and collectivity, singularity and sociality. Nonetheless, I argue that it is necessary to find a justification for such analogies. If Husserl anchors his notion of analogy in the fundamental self-certitude of the transcendental subject, endowing the ego with an Olympian perspective, Ricœur's preoccupation with the relations that can be analogically applied to individual and community offers up an alternative ground.

I think that Ricœur's account of the analogy between individual and collective memory finds its own justification in his broader hermeneutics of symbols. It is within the symbolic framework that individual memory can interact with societal memory. But what does Ricœur mean with the concept of symbol in relation to the problem of collective memory? It seems to me essential to briefly clarify this difficult point. Surprisingly, we can observe that in his discussion of collective memory in Memory, History, Forgetting, the French author does not present any adequate analysis of the role and the function of the symbol in bringing about social cohesion ${ }^{61}$. Yet, the notion of symbol takes different meanings in the different periods of Ricœur's thought. To simplify, we can recall two principal articulations of the concept of symbol in his oeuvre. The first articulation relates to the narrow sense of the term symbol as a superior realm, i.e., as a figuration of what cannot be grasped in the domain of direct experience such as the lamb as the liturgical

\footnotetext{
${ }^{59}$ Barash, Jeffrey Andrew. Collective Memory and the Historical Past, p. 74.

${ }^{60}$ Ricœur, Paul. Memory, History, Forgetting, p. 119.

${ }^{61}$ Barash, Jeffrey Andrew. The Time of Collective Memory. Études Ricœuriennes/Ricœur Studies, v. 10, n. 1, 2019 , p. 104.
} 
symbol of Israel's deliverance. This conception, which is tied to the Christian tradition, is developed in Ricœur's book On Interpretation: Essay on Freud (1965) against Ernst Cassirer's theory of symbol, elaborated in his Philosophy of Symbolic Forms (1923), as far too broad. The second articulation of the concept of the symbol relates to the broad sense of it. A little more than a decade later in the first volume of Time and Narrative (1983) Ricœur's changes his mind but without ever explicitly referring to this change in his writings. Drawing directly on the perspective of Cassirer, Ricœur writes: "symbolic forms are cultural processes that articulate experience as a whole. If I speak more precisely of symbolic mediation, it is to distinguish, among symbols of a cultural nature, the ones that underlie action and that constitute its first signification" ${ }^{62}$. What is of particular importance in my discussion on collective memory is the concept of symbolic mediation. With reference to Cassirer and to the conception of symbol elaborated by the American anthropologist Clifford Geertz in his book The Interpretation of Cultures (1973), the notion of symbolic mediation allows Ricœur to reintroduce in his mature thought the theory of the symbol as a source of intersubjective cohesion. The configuration of the public sphere depends on the interpretation and the communication of the fragmented symbolic networks, which have interwoven significances according to the perspective of the group that interprets them. As Barash puts it, "it is through the cohesion and continuity of these intertwined symbolic networks that the past and the present are joined together in a horizon of experience and remembrance that is turned toward the future, shared by contemporary generations of different ages whose lifespans overlap"63. Although in Memory, History, Forgetting, Ricœur does not relate to the theory of symbol deployed in Cassirer's thought and the anthropology of Geertz to his theory of collective memory, it seems to me clear that these two theories constitute the background to understand the use of the notion of symbol in his phenomenology of collective memory. Otherwise put, Ricœur's phenomenology of memory can be, then, understood in connection with his hermeneutics of symbols, namely with the possibility to interpret the multiplicity of social contexts as symbolic frameworks in which human actions take place. Briefly stated, the symbol has a fundamental role for understanding the analogies that individual and community presuppose. Through the mediation of the symbolic engagement, human being's individual awareness is inserted within the "intersubjective cohesion refracted in the fragmented perspectives of the groups that are engaged in collective relations" 64 . In this way, Ricœur claims that there is a mutual building up between individual and collective memory. These presuppositions lead him to the hypothesis of a triple assignment of memory: to ourselves as individuals, to close relationships, and to others.

\footnotetext{
${ }^{62}$ Ricœur, Paul. Time and Narrative, vol. 1, p. 57.

${ }^{63}$ Barash, Jeffrey Andrew. The Time of Collective Memory, p. 107.

${ }^{64}$ Barash, Jeffrey Andrew. Collective Memory and the Historical Past, p. 75.
} 
Ricœur suggests, then, that there is "an intermediate level of reference between the poles of individual memory and collective memory, where concrete exchanges operate between the living memory of individual persons and the public memory of the communities to which we belong" ${ }^{65}$. Yet, he adds that "it is, therefore, not with the sole hypothesis of the polarity between individual memory and collective memory that we must enter into the field of history, but with the hypothesis of the threefold attribution of memory: to oneself, to one's close relations, and to others" ${ }^{66}$. The relations with closely related persons "occupy the middle-ground between the self and the "they" ${ }^{\prime 6}$. These closely related persons are people, "who count for us, and from whom we count" 68 . Through these relations I can approve the fact that I am existentially able "to speak, act, recount, impute to myself responsibility for my actions" ${ }^{69}$. To remember means, therefore, to rediscover our existential social situatedness. It is only through self-attestation arising from the relations with the others that memory is made concrete. Following Ricœur's phenomenology of memory, we can argue that re-membering, resting on symbolic mediation, is set on the path of mutuality as social shared con-textuality. In conclusion, I think that Ricœur's phenomenology of memory cannot be understood without his hermeneutic of symbol since there is no memory that is not mapped into an already existing social inhabited space, in which the collective communicability of experience finds its own place.

\section{Conclusion}

Through the application of the phenomenological, sociological, and historical tools, in this article I have explored Ricœur's approach to collective memory from his epistemological and hermeneutical analysis to his socio-phenomenolgical perspective. We have emphasized three major points. First, we have seen that the individual consciousness cannot be considered as ultimate foundation of collective memory. Second, drawing upon phenomenological resources, we have focused the attention on the singularity of lived experience and lived subjectivity. As such, we have understood that in Ricœur's perspective collective memory cannot be considered neither as a sort of objective spirit nor as the mere addition of individual memories. In short, collective memory has emerged in its historical dimension as a dynamic and vulnerable phenomenon linked to the prefiguration, the configuration and the re-configuration of social reality. Let me offer now a few concluding remarks.

\footnotetext{
${ }^{65}$ Ricœur, Paul. Memory, History, Forgetting, p. 131.

${ }^{66}$ Ricœur, Paul. Memory, History, Forgetting, p. 132.

${ }^{67}$ Ricœur, Paul. Memory, History, Forgetting, p. 131.

${ }^{68}$ Ricœur, Paul. Memory, History, Forgetting, p. 131.

${ }^{69}$ Ricœur, Paul. Memory, History, Forgetting, p. 132.
} 
Ricœur's approach clearly shows that memory can neither be limited to the personal capacity to remember belonging to a singular individual, nor can collective memory be considered as a sort of objective spirit invoking a holistic perspective. Otherwise put, memory is at the crossroad of history, personal identity, and community. Characterized by a temporal tangle, memory is a dynamic phenomenon that plays a key role of actualization, re-actualization and re-activation of the past. The representation of the past has a social importance and can be considered as a major societal challenge. Memory works through images and narrative imagination. Memory is, then, mostly narrative and can be regarded as a laboratory in which possible human individual and collective realities can be tested. As such, remembering is directly linked to human ability to use language and to tell stories, as well as to the problem of truth-claims and to the idea of narrative identity. According to Ricoeur, human being's collective and individual identities are not static structures, but rather on-going tasks, processes of constancy and rectification that synthesizes the horizons of past, present, and future. Through the mediation of the narrative function, memories are transformed in personal and common stories, that is, in declarative plots in which the events are grasped together in a coherent and meaningful causal network. Linked to the complex development of his hermeneutics of symbols, Ricoeur's theory of collective memory reveals its critical purpose and its productive exercise.

\section{References}

BARASH, Jeffrey Andrew. Collective Memory and the Historical Past. Chicago: Chicago University Press, 2016.

BARASH, Jeffrey Andrew. The Politics of Memory. In: M. Dooley and R. Kearney (Eds.). Questioning Ethics: Contemporary Debates in Continental Philosophy. London: Routledge, pp. 33-34, 1999.

BARASH, Jeffrey Andrew. The Place of Remembrance. In: B. Treanor and H. I. Venema (Eds.). A Passion for the Possible: Thinking with Paul Ricour. New York: Fordham University Press, pp. 147-157, 2010.

BARASH, Jeffrey Andrew. The Time of Collective Memory. Études Ricouriennes/Ricœur Studies, v. 10, n. 1, 2019, pp. 102-111.

BEVAN, Robert. The Destruction of Memory: Architecture at War. London: Reaktion Books, 2006.

HALBWACHS, Maurice. On Collective Memory. Chicago: Chicago University Press, 1992. 
HELENIUS, Timo. Ricour, Culture, and Recognition: A Hermeneutic of Cultural Subjectivity. London: Lexington, 2016.

KEARNEY, R. Narrative Imagination: between Ethics and Poetics. In: R. Kearney (Ed.). The Hermeneutics of Action. London: Sage, pp. 173-190, 1996.

KLEMM, D. Philosophy and Kerygma. Ricœur as Reader of the Bible. In: D. Kaplan (Ed.). Reading Ricœur. New York: State University of New York Press, pp. 47-70, 2008.

LOCKE, John. An Essay Concerning Human Understanding (1689). London: Dent, 1976.

MICHEL, Johann. Introduction to Mémoires et Histoires. Des identités personnelles aux politiques de reconnaissance. Rennes : Presses Universitaires de Rennes, 2005.

NORA, Pierre. Between Memory and History: Les Lieux de Mémoire. Representations, Special Issue: Memory and Counter-Memory, v. 26, n. 1, 1989, pp. 7-25.

PELLAUER, David. Ricour: A Guide for the Perplexed. London: Continuum, 2007.

RICEUR, Paul. Time and Narrative, vol. 1. Chicago: Chicago University Press, 1984.

RICEEUR, Paul. Time and Narrative, vol. 3. Chicago: Chicago University Press, 1988.

RICEEUR, Paul. Oneself as Another. Chicago: Chicago University Press, 1992.

RICEUUR, Paul. Memory, History, Forgetting. Chicago: Chicago University Press, 2004.

RICEUR, Paul. The Course of Recognition. Cambridge: Harvard University Press, 2005. 